medRxiv preprint doi: https://doi.org/10.1101/2020.08.21.20179499; this version posted August 24, 2020. The copyright holder for this preprint (which was not certified by peer review) is the author/funder, who has granted medRxiv a license to display the preprint in All rights reserved. No reuse allowed without permission.

1 The effect of BMI and physical activity levels on the duration of symptomatic days with 2

\title{
Covid-19 infection.
}

3 Abdulazeem S Alataibi ${ }^{1}$ and Boukhemis Boukelia ${ }^{2,3}$

$4 \quad{ }^{1} \mathrm{Al}$ Qasseem University, Al Qaseem, P.O.Box 6688. KSA. ${ }^{2}$ Hull University, Cottingham

5 Road, Hull HU6 7RX. UK. ${ }^{3}$ Britannia Sport and Exericse Science Academy. 6/7 Duff street

6 lane Edinburgh. UK.

7

8 Abstract

9 Regular exercise is known to boost immunity, increase immune response to fight infection, as

10 well as speeding up recovery times and healing processes. This study seeks to assess if 11 exercising regularly pre- SARS-CoV-2 (COVID-19) and/or BMI status has an effect on

12 recovery time.

13 A total of 215 people infected with COVD-19 from the Kingdom of Saudi Arabia took part in 14 this study (age $36 \pm 16$ years, mass $72 \pm 15 \mathrm{~kg}$, stature $166 \pm 11 \mathrm{~cm}$ ). Only 10 patients were physically active and fulfil WHO physical activity requirement (Age 30 \pm 7 years, Mass $77 \pm 9$ $\mathrm{kg}$, Stature $176 \pm 1 \mathrm{~cm})$.

There was a significant difference in recovery time between active and inactive patients $(\mathrm{P}=0.00)$ with active patients' recovery 2.7 times faster than inactive patients. Active patients showed a lower BMI level ( $\mathrm{p}=0.043)$.

Anthropometric measurement characteristics and the fitness level could be used in decision making scenarios for the estimation of the risk of complications in patients with COVID-19. Novelty:

- Covid-19 physical active patients shows faster recovery time.

- Active patients recorded a BMI of over $25 \mathrm{~kg} / \mathrm{m}^{2}$, recovered faster than those inactive patients with similar BMI's. 
medRxiv preprint doi: https://doi.org/10.1101/2020.08.21.20179499; this version posted August 24, 2020. The copyright holder for this preprint (which was not certified by peer review) is the author/funder, who has granted medRxiv a license to display the preprint in All rights reserved. No reuse allowed without permission.

\section{Introduction}

29 The rapid spread of the corona virus that causes COVID-19 (SARS-CoV-2) has sparked alarm worldwide. The way the virus spreads is still debated; however, it is known that similar viruses are spread in cough and sneeze droplets and possibly in aerosols. At the time of writing this manuscript over eleven million people worldwide have been infected with over five hundred thousand deaths (WHO, 2020). Symptoms of COVID-19 are often mild and begin gradually, and include fever, fatigue, dry cough, some pain and aches, nasal congestion, cold, sore throat, and diarrhea (Zheng et al., 2020), whereas some people become infected without showing any symptoms at all. The prevalence of developing COVID-19 symptoms among populations with chronic disease are high (Pablos et al., 2020). In Garg et al. (2020), among patients aged 1849 years, obesity was the most prevalent underlying condition, followed by asthma and diabetes mellitus. In patients over 50 years, obesity was most prevalent, followed by hypertension. It has also been reported that COVID-19 is more likely to occur in older and adults' people within weaker immune functions (Chen et al., 2020).

It is well documented that physical activity stimulates the human immune system and strengthens the infection defence system (Simpson et al., 2006). Moreover, evidence suggests that sedentary people who become physically active get a progressively stronger immune system and become less susceptible to infections (Nash, 1994). Hence, many studies support the concept that engaging in regular bouts of moderate aerobic exercise protect against respiratory infections (Nieman et al., 1993; Nieman et al., 2011; Boukelia et al., 2016). For example, the risk of upper respiratory tract infection reduced by up to $67 \%$ compared to sedentary population (Gleeson, 2007) Outstandingly, 20-40 minutes of moderate daily exercise was reported to be adequate to promote a beneficial effect on the immune system. This exercise-induced protection against infection can be achieved with many types of aerobic 
medRxiv preprint doi: https://doi.org/10.1101/2020.08.21.20179499; this version posted August 24, 2020. The copyright holder for this preprint (which was not certified by peer review) is the author/funder, who has granted medRxiv a license to display the preprint in All rights reserved. No reuse allowed without permission.

activity such as running, swimming, walking, and dancing (Nieman et al., 2011). The mechanism behind the moderate exercise protection against respiratory infection remain debated. Nonetheless, there are several possible reasons to explain this, such as, an increase in natural killer cells, neutrophils, and antibodies in the blood stream (Miles et al., 2002). For each bout of exercise, the human body mobilizes billions of immune cells types that are capable of recognising and killing virus-infected cells. In addition, exercise also releases muscle-derived cytokines which help to maintain immunity such as IL-6, IL-7, and IL-15. IL-6 has been shown to mobilise immune cell to the infected area, while IL-7 helps to maintain the peripheral T-cell and NK-cell compartments which assist to increase the human body resistance to infection (Simpson, 2020). Furthermore, improved psychological well-being could be another possible factor (emotional stress control).

The Kingdom of Saudi Arabia has been reporting an average of 11.1 cases per 100,000 people with a mortality rate of $0.91 \%$ (MOH 2020). WHO ranks the outbreak of COVID-19 at the orange risk level (the second highest risk category) which means it is quickly spreading (WHO, 2020). A preventative measure for reducing the likelihood of this or future infections may be found through increased activity and reduced obesity within the population.

Three quarters of the adult population are classified as inactive in KSA (Al-Hazzaa, et al., 2011), following similar trends of developed countries across the world. Nevertheless, this sedentary lifestyle has been associated with a greater risk of early mortality from obesity related diseases that equate to $6 \%$ of the total death rate globally each year (Henriksen et al., 2019). This study aims to investigate the effect of fitness level on the rate of recovery time among positive COVID-19 tested in KSA. 
medRxiv preprint doi: https://doi.org/10.1101/2020.08.21.20179499; this version posted August 24, 2020. The copyright holder for this preprint (which was not certified by peer review) is the author/funder, who has granted medRxiv a license to display the preprint in All rights reserved. No reuse allowed without permission.

\section{Methodology}

78 A questionnaire developed by the Health and Exercise Science Department at al Qassim

79 University, KSA were used in this study. A 12 multiple choice questionnaire using a self-rated scale was used to evaluate the effect of fitness level on the recovery time in SARS-CoV-2 (COVID-19) patients. 215 (mean age $\pm 36.3 \pm 16.2$ ) COVID-19 infected participants from the region of Riyadh, KSA took part in this study. All infected patients observed self-isolation within medically monitored hotels and kept away from their families to minimize the risk of spreading the virus. All patients were under direct supervision of a medical team and received daily assessment on their state of health, patients that tested negative for the virus were allowed to return home. The participants were divided into two groups, a sedentary group and an active group that fulfills WHO activity criteria (no less than 150 minutes of physical activity a week). Analysis of the data revealed that from a total of 215 patients only 10 patients exercise routinely pre-positive test and fulfill the activity recommendation by WHO (150 mins a week). Body mass, age, ethnicity, diet, and sleep level were recorded as well.

All participants provided fully informed written consent before engaging with the experiment. This study was approved by the Al Qassim University Ethics Committee and was conducted in accordance with the guidelines of the 1964 Declaration of Helsinki and its later amendments or comparable ethical standards.

Statistical Analysis: Prior to statistical analysis, all data were checked for normality. Repeated measure $\mathrm{T}$ tests were used to determine significance difference in Active and Inactive patients and BMI in both groups (SPSS20 Statistical Software, IBM.UK). Statistical significance was accepted at $\mathrm{P}<0.05$. Results are represented as mean values \pm standard deviation (SD). Cohen's d was used to assess the size of the difference between two related sample. 
medRxiv preprint doi: https://doi.org/10.1101/2020.08.21.20179499; this version posted August $24,2020$. The copyright holder for this preprint (which was not certified by peer review) is the author/funder, who has granted medRxiv a license to display the preprint in All rights reserved. No reuse allowed without permission.

\section{Results}

101 Table 1: Anthropometric measurements

102 Table 2: The average sleeping hours pre and during the quarantine period.

103

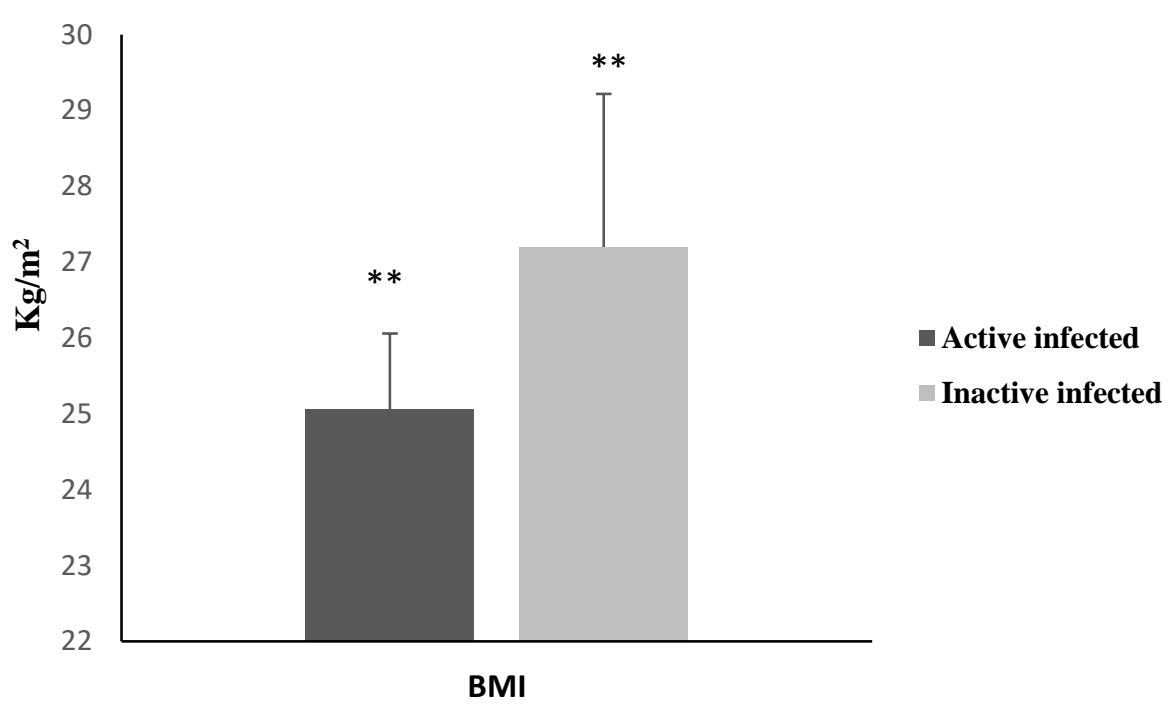

105 Graph 1: Active vs inactive tested Covid-19 positive BMI. ** denotes a significant different

106 between active and inactive patients BMI $(\mathrm{P}<0.05)$, values are mean \pm SD.

107

108 There was a significant BMI difference between active and inactive patients $\mathrm{t}(19)=2.15$, $109 \mathrm{p}=0.043($ graph 1$)$. 
medRxiv preprint doi: https://doi.org/10.1101/2020.08.21.20179499; this version posted August 24, 2020. The copyright holder for this preprint (which was not certified by peer review) is the author/funder, who has granted medRxiv a license to display the preprint in All rights reserved. No reuse allowed without permission.

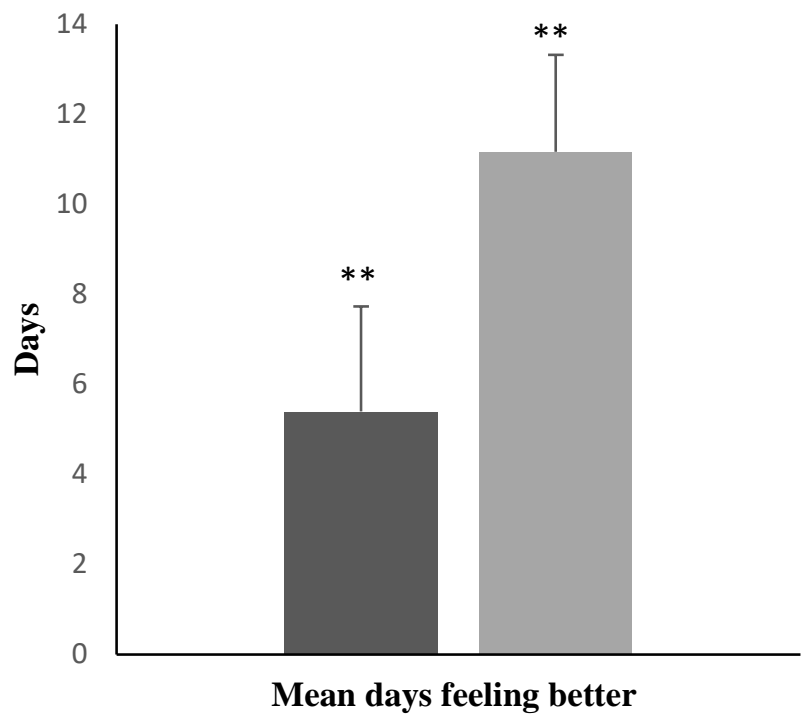

- Active-recovery time

Inactive-recovery time

111 Graph 2: the mean days of feeling better active vs inactive infected patients. **denotes a 112 significant different between active and inactive patients in the time of feeling better $(\mathrm{P}<0.05)$, 113 values are mean \pm SD

114 Inactive patients shows a significant slower recovery time compared to active patients $\mathrm{t}(19)=$

$1153.29, \mathrm{p}=0.004$ (graph 2). Active patients were recovered 2.7 times faster from COVID-19

116 infection than the group of inactive infected patients.

117

118

119

120

121

122

123

124

125

126

127

128

129

130

131

132 
medRxiv preprint doi: https://doi.org/10.1101/2020.08.21.20179499; this version posted August 24, 2020. The copyright holder for this preprint (which was not certified by peer review) is the author/funder, who has granted medRxiv a license to display the preprint in All rights reserved. No reuse allowed without permission.

\section{Discussion}

134 To date this is the first study to assess the effect that the level of physical activity and recovery period on COVID-19 infected patients. Therefore, this study provides evidence-based insights on the relationship between inactivity, higher BMI, and COVID-19 recovery time. Only $4 \%$ of

137 the patients in this study were physically active in either amateur sport or recreational physical 138 exercise that fulfil the WHO recommended level of activity requirement. A significant 139 difference in BMI between active and inactive patients were evident in this study and has been 140 shown to have a significant difference on the duration of recovery. the recovery period for the 141 inactive population was slower by $207 \%$ compared to active patients. The outcome of this study 142 supports the finding that individuals with higher BMI are more likely to have respiratory 143 symptoms than individuals with a normal BMI (Gibson, 2000; El-Gamal et al., 2005; Babb et 144 al., 2008). In a new report revealed by PHE, (2020) patients with over $25 \mathrm{~kg} / \mathrm{m}^{2}$ of BMI 145 (clinically overweight) are more than three times more likely to die of COVID-19 and seven times more likely to need a ventilator. In Stefan et al. (2020) $85 \%$ of patients with higher BMI

147 required mechanical ventilation and $62 \%$ of the patients with higher BMI died of COVID-19, 148 compared with $36 \%$ of those with a healthy weight.

150 Despite meeting the WHO recommended activity levels 4 out of 8 active patients in this study recorded a BMI of over $25 \mathrm{~kg} / \mathrm{m}^{2}$ BMI of over $25 \mathrm{~kg} / \mathrm{m} 2$, nevertheless, they likewise recovered faster than those inactive patients with similar BMI's (an average of 3.75 days vs 10 days). Therefore, it has reported that increasing physical activity including those currently 154 overweight, can reduce the risk of cardiovascular disease and improve health by being physically active (Koolhaas et al., 2017). The average participant age from this study of 215 was $36 \pm 16$ years old. Therefore, this study would support the findings of Kass et al. (2020) that

157 found a significant inverse correlation between age and BMI, in which younger individuals that 
medRxiv preprint doi: https://doi.org/10.1101/2020.08.21.20179499; this version posted August 24, 2020. The copyright holder for this preprint (which was not certified by peer review) is the author/funder, who has granted medRxiv a license to display the preprint in All rights reserved. No reuse allowed without permission. a rising obesity problem with approximately $40 \%$ of the total population categorised as obese (Alqarni, 2016). Therefore, this phenomenon may contribute to the fast spread and increased symptom severity and/or duration of COVID-19; that would consequently greatly stress the national health service.

163

164 It must be considered that the low proportion of physically active patients recorded in this study may in fact be linked to asymptomatic infections that have remained undetected in the general population. Therefore, measurement of anthropometric characteristics and the level of activity

167 could be key to estimating the risk of complications in patients with COVID-19. In addition, countries with high overweight or obese populations should adequately characterise the risk obesity poses in relation to COVID-19 symptoms alongside other contributing factors or risk. Individuals carrying excess weight will have poor responsiveness to vaccination against

172 COVID-19 due to the impaired activation and function of $\mathrm{t}$ cells adaptive immune cells (Green and Beck, 2017), however, the development of novel immunization strategies for this population is warranted.

\section{Conflicts of Interest}

177 The authors of this publication were support and sponsored by Qassim University. The authors

178 were wholly responsible for the research conducted in this paper and present the work without conflict of interest. 
medRxiv preprint doi: https://doi.org/10.1101/2020.08.21.20179499; this version posted August 24, 2020. The copyright holder for this preprint (which was not certified by peer review) is the author/funder, who has granted medRxiv a license to display the preprint in All rights reserved. No reuse allowed without permission.

182

183

184

185

186

187

188

189

190

191

192

193

194

195

196

197

198

199

200

201

202

203

204

205

206 Green, W.D and Beck, M.B. 2017. Obesity Impairs the Adaptive Immune Response to

207 Influenza Virus. Ann Am Thorac Soc. 14(5): S406-S409.

Alqarni, S.S.M. 2016. A Review of Prevalence of Obesity in Saudi Arabia. Obesity \& Eating Disorders. 2. 2:25.

Babb, T.G, Ranasinghe, K.G, Comeau, L.A, Semon, T.L and Schwartz, B. 2008. Dyspnoea on exertion in obese women. Am J Respir Crit Care Med. 178:116-123.

Chen, N., Zhou, M., Dong,X., et al. 2020. Epidemiological and clinical characteristics of 99 cases of 2019 novel coronavirus pneumonia in Wuhan, China: a descriptive study[J]

Lancet. 395; 507-m13.

El-Gamal, H, Khayat, A, Shikora, S and Unterborn, J.N. 2005. Relationship of dyspnoea to respiratory drive and pulmonary function tests in obese patients before and after weight loss. Chest. 128:3870-3874.

Garg, S., Kim, L., Whitaker, M., et al. 2020. Hospitalization Rates and Characteristics of Patients Hospitalized with Laboratory-Confirmed Coronavirus Disease 2019 - COVID-NET, 14 States. MMWR Morb Mortal Wkly Rep. 69:458-464.

Gibson, G.J. 2000. Obesity, respiratory function and breathlessness. Thorax. 55: S41-S44.

Gleeson, M. Immune function in sport and exercise. 2007. J Appl Physiol. 103: 693-699. 
medRxiv preprint doi: https://doi.org/10.1101/2020.08.21.20179499; this version posted August 24,2020 . The copyright holder for this preprint (which was not certified by peer review) is the author/funder, who has granted medRxiv a license to display the preprint in All rights reserved. No reuse allowed without permission.

208 Miles, M.P., Kraemer, W.J, Grove, D.S, Leach, S.K, Dohi, K, Bush, J.A, Marx, J.O, Nindl,

209 B.C., Volek, J.S and Mastro, A.M . 2002. Effects of resistance training on resting immune

210 parameters in women. European Journal of Applied Physiology. 87: 506-508.

211

212 Ministry of health. 2020. COVID-19 cases with the mortality rate.

213 https://www.moh.gov.sa/en/Pages/Default.aspx

214

215 Nash, M.S. 1994. Exercise and immunology. Medicine and Science in Sports and Exercise.

$21626(2): 125-7$

217

218 Nieman, D.C, Henson,D.A., Austin, M.D and Sha, W. 2011. Upper respiratory tract infection

219 is reduced in physically fi $\mathrm{t}$ and active adults. British Journal of Sports Medicine. 45(12):98792.

Nieman, D.C., Henson, D.A, Gusewitch, G., Warren, B.J, Dotson, R.C, Butterworth, D.E and

Nehlsen-Cannarella, S.L. 1993. Physical activity and immune function in elderly women.

Medicine and Science in Sports and Exercise. 25: 823-831, 1993.

Pablos, J, L., Abasolo, L., Alvaro-Gracia, J.M, et al. 2020. Prevalence of hospital PCRconfirmed COVID-19 cases in patients with chronic inflammatory and autoimmune rheumatic diseases. Annals of the Rheumatic Diseases. 10.1136- 217763.

229

230 Public health England (2020). publications gateway number: GW-1405. 
medRxiv preprint doi: https://doi.org/10.1101/2020.08.21.20179499; this version posted August 24, 2020. The copyright holder for this preprint (which was not certified by peer review) is the author/funder, who has granted medRxiv a license to display the preprint in All rights reserved. No reuse allowed without permission.

232 Kass, D.A, Duggal,,P and Cingolani, O. 2020. Obesity could shift severe COVID-19 disease to 233 younger ages. The lancet.395, 10236, 1544-1545.

234

235 Koolhaas, C.M., Dhana, K, Schoufour., J.D., Ikram,,M..A., Kavousi, M and Franco,„O..H. 236 2017. Impact of physical activity on the association of overweight and obesity with 237 cardiovascular disease: The Rotterdam Stud. European Journal of Preventive Cardiology. 24(9) 933-940.

239

240 Simpson, R.J. 2020. Exercise, Immunity and the COVID-19 Pandemic. American college of sport sceince. 3

242

243 Simpson, R. J., Florida-James, G. D., Whyte, G. P. and Guy, K. 2006. The effects of intensive, 244 moderate and downhill treadmill running on human blood lymphocytes expressing the 245 adhesion/activation molecules CD54 (ICAM-1), CD18 (beta (2) integrin) and CD53', 246 European Journal of Applied Physiology. 97(1), 109-121.

Stefan, N., Birkenfeld, A.L., Schulze, M.B. et al. 2020. Obesity and impaired metabolic health in patients with COVID-19. Nat Rev Endocrinol 16, 341-342. 
medRxiv preprint doi: https://doi.org/10.1101/2020.08.21.20179499; this version posted August 24, 2020. The copyright holder for this preprint (which was not certified by peer review) is the author/funder, who has granted medRxiv a license to display the preprint in All rights reserved. No reuse allowed without permission.

Tables:

259 The mean age, stature and mass were presented in table 1. Active patients showed 4 years

260 younger than inactive patients. In addition, this data shows a correlation between age and

261 physical activity.

262 Table 1: Anthropometric measurements

\begin{tabular}{|l|l|l|}
\hline Measurements & Physically Active & Physically inactive \\
\hline Age (years) & $30 \pm 7$ & $34 \pm 6$ \\
\hline Stature (cm) & $176 \pm 0.1$ & $170 \pm 0.06 \mathrm{t}$ \\
\hline Mass $(\mathrm{kg})$ & $77.8 \pm 9.75$ & $78.8 \pm 7.6$ \\
\hline
\end{tabular}

264 Active patients showed better sleeping hours compared to inactive patients at pre the quarantine period (Table2). Whereas, during the quarantine period 19.4\% of active patients sleep less than 5 hours compared to $9.7 \%$ at pre-quarantine period.

Table 2: The average sleeping hours pre and during the quarantine period.

\begin{tabular}{|l|l|l|l|l|l|l|}
\hline \multirow{2}{*}{$\begin{array}{l}\text { Sleeping } \\
\text { hrs }\end{array}$} & \multicolumn{3}{|c|}{ Active (\%) } & \multicolumn{3}{c|}{ Inactive (\%) } \\
\cline { 2 - 7 } & $\begin{array}{l}\text { Pre- } \\
\text { quarantine }\end{array}$ & $\begin{array}{l}\text { During } \\
\text { quarantine }\end{array}$ & $\Delta$ & $\begin{array}{l}\text { Pre- } \\
\text { quarantine }\end{array}$ & $\begin{array}{l}\text { During } \\
\text { quarantine }\end{array}$ & $\Delta$ \\
\hline$>5 \mathrm{hrs}$ & 9.7 & 19.4 & -9.7 & 14 & 15.4 & -1.4 \\
\hline $5-7 \mathrm{hrs}$ & 19.4 & 18.1 & +1.3 & 16.8 & 21 & -4.2 \\
\hline$<7 \mathrm{hrs}$ & 70.8 & 62.5 & +8.3 & 69.2 & 63.6 & +5.6 \\
\hline
\end{tabular}


medRxiv preprint doi: https://doi.org/10.1101/2020.08.21.20179499; this version posted August $24,2020$. The copyright holder for this preprint (which was not certified by peer review) is the author/funder, who has granted medRxiv a license to display the preprint in All rights reserved. No reuse allowed without permission.

273 Figures:

274

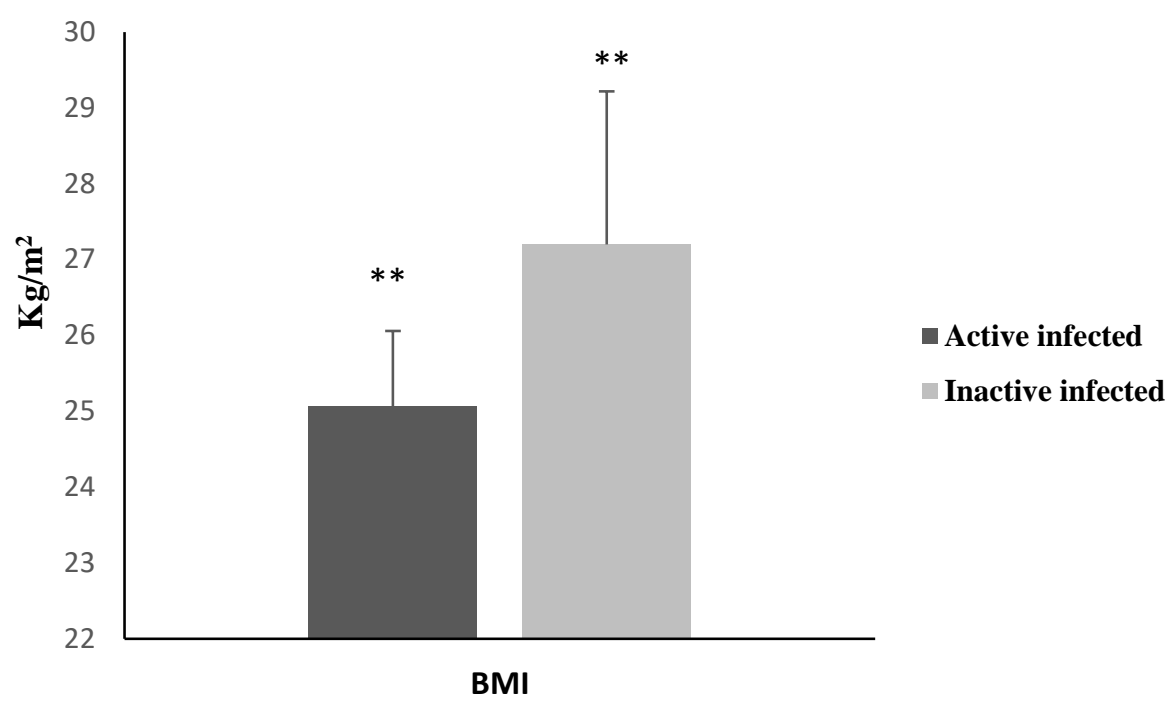

276 Graph 1: Active vs inactive tested Covid-19 positive BMI. ** denotes a significant different 277 between active and inactive patients BMI $(\mathrm{P}<0.05)$, values are mean \pm SD.

278

279 There was a significant difference between active and inactive patients BMI $\mathrm{t}(19)=2.15$, $\mathrm{p}=0.043($ graph 1). 
medRxiv preprint doi: https://doi.org/10.1101/2020.08.21.20179499; this version posted August 24, 2020. The copyright holder for this preprint (which was not certified by peer review) is the author/funder, who has granted medRxiv a license to display the preprint in All rights reserved. No reuse allowed without permission.

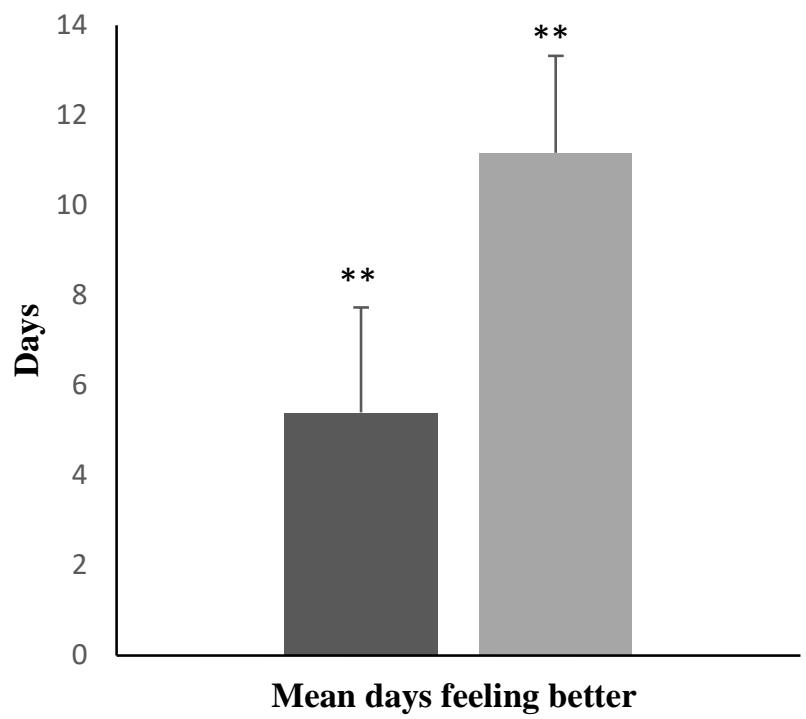

- Active-recovery time

Inactive-recovery time

283 Graph 2: the mean days of feeling better active vs inactive infected patients. **denotes a 284 significant different between active and inactive patients in the time of feeling better $(\mathrm{P}<0.05)$, 285 values are mean \pm SD

286 Inactive patients shows a significant slower recovery time compared to active patients $\mathrm{t}(19)=$ $2873.29, \mathrm{p}=0.004$ (graph 2). Active patients were recovered 2.7 times faster from COVID-19 288 infection than the group of inactive infected patients. 